\title{
Globalization and Entrepreneurship: Selected Topics in Visegrad Four Countries
}

\author{
Eva Hamplová1, ${ }^{,}$, Jaroslav Kovárník ${ }^{1}$ \\ ${ }^{1}$ University of Hradec Králové, Faculty of Informatics and Management, Department of Economics, \\ Rokitanského 62, 500 03, Hradec Králové, Czech Republic
}

\begin{abstract}
Entrepreneurship is a specific and continuous activity of an individual or a group of individuals with the aim to create a profit. It is a very important activity not only in the perspective of national economy, but also in the context of global economy. This activity can create a lot of job opportunities, especially thanks to small and medium-sized enterprises. These companies have a very important role on every market. The aim of this article is to map the development of entrepreneurship in Visegrad Group countries, namely in the Czech Republic, Poland, Slovakia, and Hungary, thanks to selected indicators between 2009 and 2017. These indicators are especially the increase of newly-established companies, their average growth rate, death rate, survival rate in all selected countries. All selected categories are consequently evaluated through one standardized criterion, which helps to compare all Visegrad Group countries and create the order of all countries with the aim to evaluate the business environment. This article opens the possibility to evaluate entrepreneurship and business environment in other countries as well, because this environment should be evaluated also in the Central European countries, European Union, or even in the OECD.
\end{abstract}

\section{Introduction}

The recognition that entrepreneurship and entrepreneurs are important drivers of economic growth, employment, innovation and productivity has been long understood by analysts and economic theoreticians, see for example, $[1,2,3,4]$. This recognition has accelerated since the mid-1990s, with policy makers in many countries and international organisations beginning to explicitly recognise the importance of entrepreneurship and making general statements about their commitment to increasing entrepreneurship or, at least, to improving the entrepreneurial environment $[5,6,7,8,9]$. However, the pursuit and development of these policies, namely the factors that affect and benefits of, entrepreneurship, are still hampered by the limited, albeit growing, empirical information relating to these factors and benefits. Where there are policy references to entrepreneurship, most simply equate it with small and medium sized enterprises (SMEs) in general, or even numbers of self-employed $[10,11,12,13,14]$. This, in part, reflects the greater availability of statistics on SMEs and the self-employed but it also reflects the general ambiguity relating to entrepreneurship.

\footnotetext{
*Corresponding author: eva.hamplova@uhk.cz
} 
The Eurostat-OECD entrepreneurship indicator programme (EIP) was created in 2007. In its current form the EIP is the result of a strong co-operation between Eurostat, the OECD and national statistical institutes. The EIP aims to collect internationally comparable statistics to enable the "measurement" of entrepreneurship i.e. to measure entrepreneurial performance and its determinants and impact. Furthermore, it aims to develop a list of indicators and standard definitions and concepts to facilitate the collection of statistics on entrepreneurship. It is important to produce statistics and develop policy relevant indicators on entrepreneurship because entrepreneurs are crucial sources of innovation, economic growth and employment creation in modern economies [15].

\section{Methodology and Data}

The set of indicators that are part of the Entrepreneurship Indicator Programme (EIP) framework are developed to different degrees. Some of them are well-established components of regular data collections, while others are only compiled in a restricted number of countries, and their harmonised definition forms the object of discussion and further work. The indicators presented in this article reflect this diversity. The statistical unit is the enterprise. In practice, many countries report data on legal units, which in most cases coincide with the enterprise. The annual Business demography data collection covers variables which explain the characteristics and demography of the business population. The methodology allows for the production of data on enterprise births (and deaths), that is, enterprise creations (cessations) that amount to the creation (dissolution) of a combination of production factors and where no other enterprises are involved. In other words, enterprises created or closed solely as a result of e.g. restructuring, merger or break-up are not considered. The data are drawn from business registers, although some countries improve the availability of data on employment and turnover by integrating other sources.

Moreover, the comparison of these indicators from analysed countries has been done through point rating. Every economy can get the number of points given by the formula:

$$
y=\frac{x-x_{\min }}{x_{\max }-x_{\min }} \cdot 100,
$$

where $y$ means the number of points, $x$ presents the value of each macroeconomic indicator for every year and every country, $x \_$min is minimal value of this indicator from all countries and the whole analysed period, and finally $x_{-} \max$ is the maximum one. Immediately from (1) it is clear that $y \in[0,100]$, the value for the worst result of $x$ is $y=0$, and the value for the best result of $\mathrm{x}$ is $\mathrm{y}=100$. The coefficient $\mathrm{y}$ is computed by one of the possible data transformation methods called nonmetric scaling; more details can be found in [16].

\section{Results}

\subsection{Entrepreneurship indicator programme}

The great challenge of the Entrepreneurship Indicator Programme (EIP) is to provide information and improve understanding of the multifaceted phenomenon of entrepreneurship and its different aspects. From the beginning the EIP program stated that no single indicator can ever capture different facets of entrepreneurship, therefore a set of measures has been developed. The 18 most important indicators are presented in the table below. 
Table 1. The most important indicators of entrepreneurial performance [17].

\begin{tabular}{|l|l|l|}
\hline \multicolumn{1}{|c|}{ Enterprises } & \multicolumn{1}{c|}{ Employment } & \multicolumn{1}{c|}{ Wealth } \\
\hline $\begin{array}{l}\text { 1. Employer enterprise net } \\
\text { growth }\end{array}$ & $\begin{array}{l}\text { 7. High growth enterprise } \\
\text { rates by employment }\end{array}$ & $\begin{array}{l}\text { 13. High growth enterprise } \\
\text { rates by turnover }\end{array}$ \\
\hline $\begin{array}{l}\text { 2. Employer enterprise birth } \\
\text { rates }\end{array}$ & $\begin{array}{l}\text { 8. Gazelle rates by } \\
\text { employment }\end{array}$ & $\begin{array}{l}\text { 14. Gazelle rates by } \\
\text { turnover }\end{array}$ \\
\hline $\begin{array}{l}\text { 3. Employer enterprise } \\
\text { death rates }\end{array}$ & $\begin{array}{l}\text { 9. Business ownership start } \\
\text { Up rates }\end{array}$ & $\begin{array}{l}\text { 15. Value added by size } \\
\text { class }\end{array}$ \\
\hline $\begin{array}{l}\text { 4. Employer enterprise } \\
\text { churn }\end{array}$ & $\begin{array}{l}\text { 10. Business ownership } \\
\text { rates }\end{array}$ & $\begin{array}{l}\text { 16. Productivity } \\
\text { contribution by size class }\end{array}$ \\
\hline $\begin{array}{l}\text { 5. Survival rates of 3 year } \\
\text { and 5 year old enterprises }\end{array}$ & $\begin{array}{l}\text { 11. Employment share of 3 } \\
\text { year and 5 year old } \\
\text { enterprises }\end{array}$ & $\begin{array}{l}\text { 17. Innovation performance } \\
\text { by size class }\end{array}$ \\
\hline $\begin{array}{l}\text { 6. Share of 3 year and 5 } \\
\text { year old enterprises }\end{array}$ & $\begin{array}{l}\text { 12. Average size of 3 year } \\
\text { and 5 year old enterprises }\end{array}$ & 18. Exports by size class \\
\hline
\end{tabular}

\subsection{Net business population growth - percentage}

The analysis of year-on-year growth in the number of active business units in Visegrad Four Countries shows that the highest increase (measured by the average value for all analysed years) is in Slovakia (3.86\%), the Czech Republic is on the second place $(2.42 \%)$, Poland is on the third position (1.44\%), and there was a decrease in case of Hungary. In other words, the number of business units in Hungary is lower in 2017 than in 2009. The evaluation of the development and the growth of business activity thanks to the average growth rate of business units has to be completed for the total number of active business units. Countries of Visegrad Four are not of the same size, there is 1 million active business units in the Czech Republic, 2 millions in Poland, 0.5 million in Hungary, and almost 0.5 million in Slovakia. Therefore, it is obvious that the number of active business units on 1000 inhabitants is important for the Czech Republic, but relatively unimportant in case of Poland. The Czech Republic and Slovakia have not only more important percent of average growth of active business units within V4 countries, but also higher number of active business units on 1000 inhabitants.

Table 2. Population of active enterprises - annual growth between 2009 - 2017 (percentage) in Visegrad Four Group countries [17, 18].

\begin{tabular}{|l|l|l|l|l|l|l|l|l|l|l|}
\hline $\begin{array}{l}\text { GEO/ } \\
\text { TIME }\end{array}$ & $\mathbf{2 0 0 9}$ & $\mathbf{2 0 1 0}$ & $\mathbf{2 0 1 1}$ & $\mathbf{2 0 1 2}$ & $\mathbf{2 0 1 3}$ & $\mathbf{2 0 1 4}$ & $\mathbf{2 0 1 5}$ & $\mathbf{2 0 1 6}$ & $\mathbf{2 0 1 7}$ & $\boldsymbol{\varnothing}$ \\
\hline CZE & 11.10 & 3.86 & 2.08 & -0.24 & -1.92 & 5.52 & 0.42 & 1.12 & -0.12 & 2.42 \\
\hline HUN & -2.78 & 0.71 & -0.97 & -5.94 & -1.68 & 1.19 & 1.74 & 0.83 & 3.82 & -0.34 \\
\hline POL & 4.11 & 2.45 & 1.36 & 0.31 & 1.27 & 0.50 & 1.71 & -2.16 & 3.38 & 1.44 \\
\hline SVK & 4.90 & 3.08 & 12.78 & -4.16 & -1.35 & 9.82 & 1.92 & 1.73 & 5.99 & 3.86 \\
\hline
\end{tabular}

\subsection{Employer enterprise birth and death}

Birth rate - the number of enterprise births in the reference period divided by the number of enterprises active in percentage. Employer Enterprise Birth is the number of an enterprise with at least one employee. This population consists of enterprise births that have at least 
one employee in the birth year and of enterprises that existed before the year in consideration, but were below the threshold of one employee.

Table 3. The number of enterprise births between 2008 - 2017 (percentage) [17, 18].

\begin{tabular}{|l|l|l|l|l|l|l|l|l|l|l|c|}
\hline $\begin{array}{l}\text { GEO/ } \\
\text { TIME }\end{array}$ & $\mathbf{2 0 0 8}$ & $\mathbf{2 0 0 9}$ & $\mathbf{2 0 1 0}$ & $\mathbf{2 0 1 1}$ & $\mathbf{2 0 1 2}$ & $\mathbf{2 0 1 3}$ & $\mathbf{2 0 1 4}$ & $\mathbf{2 0 1 5}$ & $\mathbf{2 0 1 6}$ & $\mathbf{2 0 1 7}$ & $\boldsymbol{\emptyset}$ \\
\hline CZE & 3,81 & 10,93 & 11,43 & 10,55 & 8,66 & 8,02 & 9,13 & 8,34 & 8,71 & 9,14 & 8,87 \\
\hline HUN & 10,15 & 9,17 & 10,01 & 9,98 & 8,60 & 9,86 & 9,98 & 10,69 & 10,75 & 12,86 & 10,21 \\
\hline POL & 13,15 & 12,84 & 13,81 & 12,46 & 11,52 & 12,41 & 12,50 & 12,13 & 12,32 & 12,17 & 12,53 \\
\hline SVK & 15,51 & 16,34 & 13,19 & 14,39 & 10,58 & 9,95 & 19,79 & 12,07 & 10,96 & 13,67 & 13,65 \\
\hline
\end{tabular}

Table 3 shows that the highest average percent of newly established companies in the period 2008 - 2017 was in Slovakia. On the other hand, the weakest average percent of newly established companies was in the Czech Republic. The extreme results were in case of Slovakia between 2013 and 2014 (birth rate almost 20\%), and in case of the Czech Republic between 2007 and 2008 (3.81\%). Therefore, it is not possible to make any conclusion about the impact of global economic crisis on birth rate.

Table 4. The number of enterprise deaths between 2008 - 2017 (percentage) [17, 18].

\begin{tabular}{|l|c|c|c|c|c|c|c|c|c|c|c|}
\hline $\begin{array}{l}\text { GEO/ } \\
\text { TIME }\end{array}$ & $\mathbf{2 0 0 8}$ & $\mathbf{2 0 0 9}$ & $\mathbf{2 0 1 0}$ & $\mathbf{2 0 1 1}$ & $\mathbf{2 0 1 2}$ & $\mathbf{2 0 1 3}$ & $\mathbf{2 0 1 4}$ & $\mathbf{2 0 1 5}$ & $\mathbf{2 0 1 6}$ & $\mathbf{2 0 1 7}$ & $\boldsymbol{\emptyset}$ \\
\hline CZE & 8,20 & 8,21 & 8,95 & 9,13 & 9,71 & 8,30 & 7,90 & 7,61 & 9,21 & 8,38 & 8,56 \\
\hline HUN & 10,81 & 9,64 & 11,08 & 13,49 & 11,64 & 9,02 & 8,80 & 8,21 & 12,43 & 9,98 & 10,51 \\
\hline POL & 9,00 & 10,82 & 10,58 & 11,33 & 11,20 & 11,57 & 10,62 & 9,14 & 10,52 & 10,52 & 10,53 \\
\hline SVK & 11,38 & 10,57 & 7,19 & 14,17 & 9,25 & 12,67 & 10,37 & 9,21 & 9,93 & 11,08 & 10,58 \\
\hline
\end{tabular}

The death of enterprises is an integral part of the phenomenon of entrepreneurship. Monitoring the rate of exit of firms from the market, over time and across countries, helps the understanding of the process of "creative destruction" and the impact of economic cycles on entrepreneurship.

An enterprise is included in the count of deaths only if it is not reactivated within two years. Equally, a reactivation within two years is not counted as a birth.

Table 4 describes that the lowest average percent of termination of business activity in the period 2008 - 2017 was in the Czech Republic. In all other V4 countries is this average rate almost the same. Interesting development was in Slovakia. There was the lowest yearon-year termination between 2009 and 2010, where there was the highest one year later (between 2010 and 2011). This extreme was not only in Slovakia, but it was the highest result from all V4 countries for the whole analysed period.

The churn rate, i.e. the sum of birth and death rates of enterprises, provides a measure of how frequently new firms are created and existing enterprises close down. In most economies, the number of births and deaths of enterprises is a sizeable proportion of the total number of firms. The indicator reflects a country's degree of "creative destruction", and supports the analysis of the contribution of business dynamism to aggregate productivity growth.

This indicator is not part of complex evaluation in the chapter 3.5. 


\subsection{Survival rates of $\mathbf{3}$ year and $\mathbf{5}$ year old enterprises}

Survival rate 3: the number of enterprises in the reference period newly born in t-3 having survived to $t$ divided by the number of enterprise.

In the Business Demography context, survival occurs if an enterprise is active in terms of employment and/or turnover in the year of birth and the following year(s). Two types of survival can be distinguished:

1. An enterprise born in year $\mathrm{xx}$ is considered to have survived in year $\mathrm{xx}+1$ if it is active in terms of turnover and/or employment in any part of year $\mathrm{xx}+1$ (= survival without changes).

2. An enterprise is also considered to have survived if the linked legal unit(s) have ceased to be active, but their activity has been taken over by a new legal unit set up specifically to take over the factors of production of that enterprise (= survival by takeover).

Table 5. Survival rate 3 between 2008 - 2017 (percentage) [17, 18].

\begin{tabular}{|l|c|c|c|c|c|c|c|c|c|c|c|}
\hline GEO/TIME & $\mathbf{2 0 0 8}$ & $\mathbf{2 0 0 9}$ & $\mathbf{2 0 1 0}$ & $\mathbf{2 0 1 1}$ & $\mathbf{2 0 1 2}$ & $\mathbf{2 0 1 3}$ & $\mathbf{2 0 1 4}$ & $\mathbf{2 0 1 5}$ & $\mathbf{2 0 1 6}$ & $\mathbf{2 0 1 7}$ & $\boldsymbol{\varnothing}$ \\
\hline CZE & 56,39 & 55,75 & 58,50 & 60,44 & 56,58 & 56,73 & 55,24 & 56,49 & 59,51 & 61,07 & 57,67 \\
\hline HUN & 52,12 & 52,35 & 51,34 & 50,32 & 50,04 & 46,61 & 48,58 & 53,24 & 59,31 & 53,23 & 51,71 \\
\hline POL & 56,13 & 58,09 & 58,84 & 55,67 & 54,10 & 54,07 & 52,49 & 54,24 & 51,99 & 53,36 & 54,90 \\
\hline SVK & 55,77 & 50,59 & 43,15 & 55,33 & 51,33 & 53,71 & 51,65 & 58,39 & 65,66 & 58,05 & 54,36 \\
\hline
\end{tabular}

Table 5 shows that the highest average percent of companies which have survived for at least three years from their establishing was in the Czech Republic. Very similar development is in Poland and in Slovakia, and the lowest average percent of survival rate 3 between 2008 and 2017 was in Hungary. The lowest survival rate was in 2010 in Slovakia, and the highest also in Slovakia in 2016. The simple analysis of survival rate 3 shows that higher percent of this indicator were in last 2 analysed years that means between 2016 and 2017.

Survival rate 5: the number of enterprises in the reference period newly born in $t-5$ having survived to $t$ divided by the number of enterprise.

Table 6. Survival rate 5 between $2008-2017$ (percentage) $[17,18]$.

\begin{tabular}{|l|c|c|c|c|c|c|c|c|c|c|}
\hline $\begin{array}{l}\text { GEO/ } \\
\text { TIME }\end{array}$ & $\mathbf{2 0 0 9}$ & $\mathbf{2 0 1 0}$ & $\mathbf{2 0 1 1}$ & $\mathbf{2 0 1 2}$ & $\mathbf{2 0 1 3}$ & $\mathbf{2 0 1 4}$ & $\mathbf{2 0 1 5}$ & $\mathbf{2 0 1 6}$ & $\mathbf{2 0 1 7}$ & $\boldsymbol{\emptyset}$ \\
\hline CZE & 44,79 & 44,32 & 44,49 & 46,39 & 49,53 & 43,93 & 44,88 & 44,47 & 45,29 & 45,34 \\
\hline HUN & 40,31 & 38,89 & 38,56 & 36,51 & 36,12 & 37,12 & 35,90 & 36,65 & 38,62 & 37,63 \\
\hline POL & 44,79 & 43,89 & 43,81 & 44,28 & 40,92 & 39,60 & 40,57 & 39,31 & 41,12 & 42,03 \\
\hline SVK & 44,38 & 41,86 & 40,45 & 34,90 & 42,37 & 37,50 & 39,97 & 40,78 & 47,36 & 41,06 \\
\hline
\end{tabular}

The average percent of companies which have survived for at least five years from their establishing (survival rate 5) is the highest in the Czech Republic. The difference between the Czech Republic and Hungary is growing thanks to this indicator. Extreme results were in Slovakia in 2012 (the lowest average value of survival rate 5) and in the Czech Republic in 2013 (the highest average value of survival rate 5). This value is almost 50\%, which means that in this year in the Czech Republic almost every second company established in 
2009 had some business activity or at least one employee in its fifth year of existence. This value was not overcome in any other country or any other year.

\subsection{The Analysis of Business Demography by Nonmetric Scaling}

As was mentioned in methodology part, the method of point rating has been used for this analysis. Fife different entrepreneur indicators have been used for the rating. namely Net business population growth - percentage (A), Birth rate (B), Death rate (C), Survival rate 3 (D) and Survival rate 5 (E). The analysed period for this analysis is $2009-2017$, because it is possible to find enough data for such analysis. However, in the analysis are compared the years 2009 and 2017, where points in every country in every analysed indicator have been calculated and summed up.

Table 7. Indicators of Business Demography in the years 2009 and 2017 [17, 18].

\begin{tabular}{|l|c|c|c|c|c|c|c|c|}
\hline Indicator & $\begin{array}{c}\text { CZE } \\
\mathbf{2 0 0 9}\end{array}$ & $\begin{array}{c}\text { HUN } \\
\mathbf{2 0 0 9}\end{array}$ & $\begin{array}{l}\text { POL } \\
\mathbf{2 0 0 9}\end{array}$ & $\begin{array}{l}\text { SVK } \\
\mathbf{2 0 0 9}\end{array}$ & $\begin{array}{c}\text { CZE } \\
\mathbf{2 0 1 7}\end{array}$ & $\begin{array}{c}\text { HUN } \\
\mathbf{2 0 1 7}\end{array}$ & $\begin{array}{c}\text { POL } \\
\mathbf{2 0 1 7}\end{array}$ & $\begin{array}{c}\text { SVK } \\
\mathbf{2 0 1 7}\end{array}$ \\
\hline A & 91.03 & 16.88 & 53.69 & 57.91 & 31.09 & 52.14 & 49.79 & 63.73 \\
\hline B & 24.72 & 9.77 & 40.95 & 70.69 & 9.52 & 41.12 & 35.26 & 48.00 \\
\hline C & 85.39 & 64.90 & 47.99 & 51.58 & 82.95 & 60.03 & 52.29 & 44.27 \\
\hline D & 55.98 & 40.87 & 66.37 & 33.05 & 79.61 & 44.78 & 45.36 & 66.19 \\
\hline E & 67.60 & 36.98 & 67.60 & 64.80 & 71.02 & 25.43 & 42.52 & 85.17 \\
\hline Total & $\mathbf{3 2 4 . 7 1}$ & $\mathbf{1 6 9 . 4 0}$ & $\mathbf{2 7 6 . 6 0}$ & $\mathbf{2 7 8 . 0 2}$ & $\mathbf{2 7 4 . 1 8}$ & $\mathbf{2 2 3 . 4 9}$ & $\mathbf{2 2 5 . 2 1}$ & $\mathbf{3 0 7 . 3 6}$ \\
\hline
\end{tabular}

Notes: "A" Net business population growth - percentage; "B" Birth rate: number of enterprise births in the reference period ( $\mathrm{t}$ ) divided by the number of enterprises active in $\mathrm{t}$ - percentage; " $\mathrm{C}$ " Death rate: number of enterprise deaths in the reference period ( $t$ ) divided by the number of enterprises active in $t$ - percentage; "D" Survival rate 3: number of enterprises in the reference period ( $t$ ) newly born in $t-3$ having survived to $t$ divided by the number of enterprise births in $t-3$ - percentage; "E" Survival rate 5: number of enterprises in the reference period ( $\mathrm{t}$ ) newly born in $\mathrm{t}-5$ having survived to $t$ divided by the number of enterprise births in $t-5$ - percentage

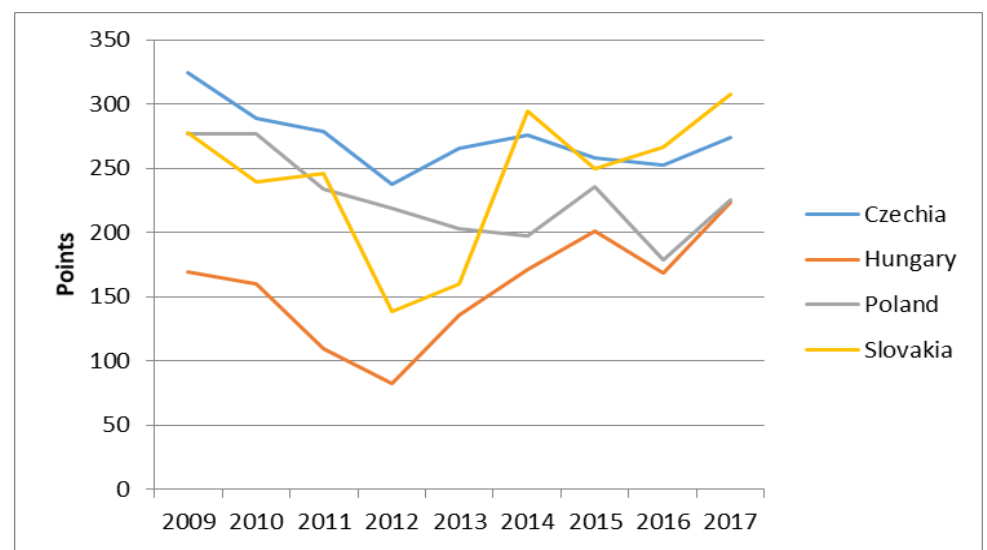

Fig. 1. Development of points in 2009 - 2017 [years, points]; (own processing based on [16, 17])

Every partial indicator (Table 7) suggests the essence of synthetic indicator and explains the reasons of change in the position of the Czech Republic in analysed period in comparison with other V4 countries. In the first analysed year was the Czech Republic in 
the evaluation of business activity unbeatably on the first place. It had overall result 324.71 points from 500, which means almost twice more than the weakest V4 country (see Figure 1). However, this situation is different in 2014, where is Slovakia on the first place. This change in the order was especially thanks to the birth rate indicator. In other words, high percent of newly established companies in Slovakia has changed its position. In the 2015, thanks to the low death rate, is the Czech Republic on the first place again. In the years 2016 and 2017 was Slovakia the best within V4 countries, therefore its lead before the Czech Republic has been growing. Positive shift was also in case of Hungary. In the last analysed year was its position almost the same as in Poland. In previous years was the situation in Hungary very bad. It had very bad results in each categories of business demography and it was on the last place in all analysed years.

\section{Conclusions}

The aim of this article was to analyse every Visegrad Four country from the perspective of business demography. The authors were using data and statistic of the European Union, where EU is dealing with this evidence, and the authors are using business demography data for the analysis of similarities and differences among V4 countries. The data were available for the period from 2009 to 2017 . It is possible to make a conclusion that very strong economy in the category of the number of active business units, newly established business units, and consequently terminated business units (so called survival rate) is the Czech Republic. At the end of analysed period is the strongest economy Slovakia. Slovakia managed successfully increase the growth of active business units, increase the percent of growth rate of newly established business units, and also increase the percent of companies, which survived for three or five years from their establishing. Relative weakness is high percent of terminated companies. Poland, despite its size and its importance within V4 Group, has not similar success as the Czech Republic and Slovakia. Business demography indicators are very low and they were even decreasing during analysed period. The last member of Visegrad Four is Hungary. It has had the lowest values of business demography indicators, but on the other hand, there has been positive tendency of these indicators since 2012. It is obvious that the size of the economy has no influence on the position of this economy within V4 with respect to the business demography evaluation. It is also obvious that analysed indicators decreased in all V4 countries after economic crisis, but it has grown in all countries since 2012, but not in the same growth rate.

This study is supported by internal research project "Investment within concept Industry 4.0", and by project IGA 2019 "Support of pedagogical work, technical equipment, and communication with experts", both at Faculty of Informatics and Management, University of Hradec Kralove, Czech Republic. It was prepared in cooperation with students of Ph.D. study at Department of Economics, namely with Ing. et Bc. Lucie Novotná and Ing. Martin Král.

\section{References}

1. Ch. Dawson, A. Henley, P. Latreille, Individual motives for choosing self-employment in the UK: does region matter? Regional studies, 48, 804-822 (2014)

2. O. Dvoulety, I. Blazkova, The impact of public grants on firm-level productivity: findings from the Czech food industry. Sustainability, 11, 552 (2019)

3. S. Shane, Why encouraging more people to become entrepreneurs is bad public policy, Small business economics, 33, 141-149, (2009) 
4. G. T. Lumpkin, G. G. Dess, Linking two dimensions of entrepreneurial orientation to firm performance: the moderating role of environment and industry life cycle. Journal of business venturing. 16, 429-451 (2001)

5. J. R. Baum, E. A. Locke, The relationship of entrepreneurial traits, skill, and motivation to subsequent venture growth. Journal of applied psychology, 89, 587-598 (2004)

6. A. Lundström, L. Stevenson, Entrepreneurship policy - theory and practices, ISEN International studies in entrepreneurship, (Springer, 2005)

7. D. M. Hart et. al., The emergence of entrepreneurship policy-governance, start-ups, and growth in the U.S. knowledge economy, (Cambridge University Press, 2013)

8. E. P. Lazear, Entrepreneurship. Journal of labor economics, 23, 649-680 (2005)

9. A. N. Hoffmann, A rough guide to entrepreneurship policy, Handbook of Research on Entrepreneurship Policy, (Edward Elgar Press, 2007)

10. D. Miller, I. Le Breton-Miller, Underdog entrepreneurs: a model of challenge-based entrepreneurship. Entrepreneurship theory and practice, 41, 7-17 (2017)

11. E. Hamplova, J. Kovarnik, P. Jedlicka, Analysis of various entrepreneurial activities and their development in the Czech Republic from 2008 to 2015, Proceedings of the 13th International scientific conference european financial system, Brno, Czech Republic, pp. 227-233, (2016)

12. E. Hamplova, J. Kovarnik, Analysis of entrepreneurship development in the Czech republic from 2008 to 2014, 19th International colloquium on regional sciences, pp. 226-232, (2016)

13. H. Lloyd-Ellis, D. Bernhardt, Enterprise, inequality and economic development. Review of economic studies, 67 147-168, (2000)

14. P. Arenius, M. Minniti, Perceptual variables and nascent entrepreneurship. Small business economics, 24, 233-247 (2005)

15. N. Ahmad, A. N. Hoffman, A Framework for addressing and measuring entrepreneurship, Entrepreneurship Indicators Steering Group (2007)

16. S. James, An Introduction to Data Analysis Using Aggregation Functions in R. Cham, (Springer, 2016)

17. Eurostat A, (August 2019). Business demography (bd). [Online]. Available: https://ec.europa.eu/eurostat/cache/metadata/en/bd_esms.htm

18. Eurostat B, (August 2019). Entrepreneurship indicators. [Online]. Available: https://ec.europa.eu/eurostat/web/structural-business-statistics/entrepreneurship/ indicators. 